\title{
Effectiveness of Teleconferencing in Nigerian Universities: A Descriptive Approach
}

\author{
Jimoh Bakare ${ }^{1}$, Chibueze Tobias Orji ${ }^{1 *}$, Joseph Oluchukwu Wogu ${ }^{2}$ \\ and Christian Alozie Ogbonna ${ }^{2}$ \\ ${ }^{1}$ Department of Industrial Technical Education, University of Nigeria Nsukka \\ ${ }^{2}$ Department of Mass Communication, University of Nigeria Nsukka \\ *tobias.orji@unn.edu.ng
}

\begin{abstract}
Nigerian universities have recently put in place some electronics-based strategies to equip students with academic and workplace skills and one of these electronics strategies is teleconferencing. For effective use of teleconferencing for educational purpose, the University of Nigeria and Nnamdi Azikiwe University introduced compulsory computer literacy courses into their curricula. Teleconferencing is a strategy that enables individuals to share resources at different locations. The study investigated the students use and worth of teleconferencing for educational purposes in Nigerian Universities. The study was a survey and was carried out in two Universities: University of Nigeria, Nsukka and Nnamdi Azikiwe University, Awka, all located in Eastern Part of Nigeria. Three hundred and ninety-nine (399) subjects were involved in the study and a 56-item unstructured questionnaire was employed for obtaining primary data. The questionnaire was validated by experts while frequency count and simple percentage were used to analyse data collected. Findings reveal that undergraduates use teleconferencing and benefited from using teleconferencing tools for educational purposes. They also identified some problems attached to the use of teleconferencing for teaching and learning. The students still prefer to be taught by using teleconferencing tools or components. Recommendations include that more teleconferencing tools should be employed for teaching and learning in Nigerian universities and the lecturers should be computer literate.
\end{abstract}

Keywords: Teleconferencing, Education, Undergraduates, Mobile Communication Technology, Information and Communication Technology

\section{Introduction}

Education is the only tool for developing the world. Education has been regarded as the only instrument for national development (Federal Government of Nigeria, 2008) and this instrument can be acquired in the universities and other similar educational institutions. Education acts as a means of imparting and acquiring knowledge through teaching and learning, especially at a school or similar institutions such as universities. However, educational activities in Nigeria seem to have stagnated at chalk, talk and print media. With globalization and information technology gaining widespread acceptance, it is important that concerted efforts be made even in the Nigeria educational processes to equip students for the challenges ahead (Adirika \& Alike, 2003). Nigerian Government in recent time, therefore, has made tremendous efforts in making sure that quality education is given to every citizenry at various institutions. Some of these efforts include: provision of information and communication technologies (ICT) facilities in schools and colleges,

Received (March 25, 2018), Review Result (May 26, 2018), Accepted (June 5, 2018)

* Corresponding Author 
capacity building of teachers in making use of the provided ICTs for teaching and learning, invitation of ICT training industries for training of students and teachers on professional usage and application of ICTs, creation of conducive environment for using ICTs and inculcation of ICT into Nigerian universities' curricula. Robert (2014) stated that application of ICT in education help inculcating lifelong and workplace skills for future challenges. Information and communication technology is an umbrella term that includes any communication device or application, such as radio, television, cellular phones, computer and network hardware and software, satellite systems, internet, among others, as well as the various services and applications associated with them, such as video conferencing and distance learning. Information technology on the other hand also comprises the acquisition, production, transformation, storage and transfer of data by electronic means in form of a vocal, fictional, textual and numeric pattern (Olaitan, Osinem, Hontoyon, \& Akeju, 2008). These help to facilitate interactions between people and machines, giving hope for massive and meaningful interchanges in academic settings. Akudolu (2004) explained that educational television, cassettes, and video tape recorders are ICT enhancement gadgets that enable the masses to learn anywhere, anyhow and at their own rate while teleconferencing gives an opportunity for the tapping of knowledge whenever and however the students want, keeping exciting interchanges and interactions at their beck and call.

\subsection{Overview of Teleconferencing}

A teleconference sometimes known as teleseminar is the live exchange and mass articulation of information among several persons and machines remote from one another but linked by a telecommunications system. Teleconferencing is electronic communication between two or more people at a distance (Lorne, 1983). Teleconferencing can connect multiple locations and can be divided into three major types: audio, video, and computer. These types can be combined for an almost endless set of applications (Lorne, 1983). Terms such as audio conferencing, telephone conferencing and phone conferencing are also sometimes used to refer to teleconferencing. Teleconference incorporates the various ways people can communicate with one another in spite of and over some distance (Adirika \&Alike, 2008). Teleconference according to Nwosu and Chijioke (2005) can take several forms such as audio conferencing, video and video-graphic conferencing, computer conferencing, multimedia conferencing, graphic communication and facsimile communications. John (2013) classified these as components of teleconferencing that are found useful in implementing educational programmes most especially in a developed world and some of the developing countries such as Nigeria. Teleconferencing is assisted by some software, which allows people who are geographically dispersed to hold conferences by means of sending and receiving multimedia data over networks. Examples of teleconferencing applications include video conference (Breiteneder, Gibbs \& Arapis, 1996; Dorcey, 1995), teleteaching (Arapis, Konstantas \& Pilioura, 1998), and telepresentation (Gemmell \& Bell, 2007). Other examples include video phone and audio chat. There exist several teleconferencing software tools/packages nowadays.

The telecommunications system in most occasions supports the teleconference by providing one or more of the following: audio, video, and/or data services by one or more means, such as a telephone. Using teleconferencing as a means of educating students is less cost, more efficient and reliable and flexible and more ideas can be shared than other means of educating people. Audio conferencing is actually telephone conferencing because telephone technology makes up the network that interconnects the conferees. To make audio conferencing more comfortable for learning, speaker phones are available to permit callers physical flexibility (Olgren \& Lorne 1982) and these works satisfactorily for up to eight or ten participants. But audio-graphics refers to the transmission of print and graphics information over telephone lines to complement voice communication with 
visuals. This system includes a variety of devices: electronic pens, blackboards, and tablets, as well as computer systems, slow scan television, microfiche, telewriters, and facsimile machines. Although not widely used, a potentially useful educational device is the electronic blackboard (Somani, 2012). Video teleconferencing combines the audio and visual media to provide interactive voice communications and television pictures and, the images include anything that can be captured by a television camera (Commonwealth Educational Media Centre for Asia, 2004). The methods used differ in the technology, but common factors contribute to the shared definition of teleconferencing: use a telecommunications channel, link people at multiple locations, interactive to provide twoway communications, dynamic to require users' active participation. Research has shown that teleconferencing enables the users in various colleges and universities to extend educational opportunities to distant locations; accommodates a variety of classes, from college credit courses to continuing education and public service programs; and provide a flexible format for meetings.

Computer conferencing is an emerging area for distance education. The computer is a major facility in computer conferencing. Computers that contain exceptional computing power, such as laptops, personal digital assistants (PDAs), tablet personal computers (PCs), cell phones, and e-book readers (Sung, Chang \& Liu, 2016) are used for setting up computer conferencing. Some universities offer credit programs completely by computer. Computer conferencing permits two or more learners to communicate with each other via computer terminals in a non-real-time mode. It behaves like electronic mail because the user can put a message into the computer and have it retrieved and answered later. Computer conferencing in most cases found relevant in course teaching, student counselling, and informed information exchange (Inglis, Ling, \& Joosten, 2002). Students receive texts and workbooks via mail which is part of the components of teleconferencing. It enables students to access common files assigned to a class, and also enable teachers to upload syllabi, lecture, grade and remark. It allows students to compose their assignment and remarks off-line, then uploads them to the common files. Students and their teachers are usually required to log on for a prescribed number of days during the week. Through computers, faculty, students and administrators have easy access to one another as well as access to database resources provided through libraries and other special academic resources. Bakare (2014) buttressed that computer and cell phones are mobile communication technologies found useful in teaching and learning. Specific software programs have been developed that permit members of a conference to interact with each other and to access a wide variety of stored information relevant to their objectives (Lorne, 1983). Using teleconferencing as a means of educating students is less cost, more efficient, more ideas can be shared and more flexible than other means of educating people. Researches have shown that experiences or knowledge and skills gained through the use of ICT always remain concrete. Ogugua (2005) stated that mobile communication technologies facilitate interaction between teachers and learners, changes learner behaviour in desired directions, makes teaching and learning more real and immediate, enhances retention of learning, makes learners to be physically involved with the learning material/process and makes learning socially interactive. Adirika and Alike (2008) now concluded in their assertion that these various values computer related gadgets in teaching and learning process are worthwhile and need to be exploited in the Nigerian educational system in order for the nation to realize the use of education to achieve national development as stated in national policy on education.

\subsection{Statement of the Problem}

In Nigerian Universities, most especially the University of Nigeria, Nsukka and Nnamdi Azikiwe University Awka in South Eastern Part of Nigeria, provisions are made to make sure that every student of these Universities is skilled in using a computer and other mobile technologies for enhancing their learning in various courses. The 
Management of these Universities mounted a lot of computer literacy programmes to make sure that every student is proficient in making use of computer and other related ICT gadgets for teaching and learning. Also, compulsory courses are introduced and Afrhub is charged with the responsibility of training students and staff in basic and short time computer literacy programmes. Even for students who majored in computer and ICT related programmes, advanced courses are in place at the Afrihub for further advancement. However, there is no empirical evidence to show and it is not clear to anyone whether these students actually acquired computer competencies by the end of the training programme to effectively apply computer/teleconferencing for teaching and learning purposes. The study is also necessitated by the fact that many lecturers have been blamed for poor or non-possession of computer skills or competencies that could make the use of teleconferencing for teaching and learning possible. Students in the Faculty of Vocational and Technical Education, Faculty of Education at UNN and NAU all take courses in computer at the Afrihub and other bodies that support quality education and it is now becomes necessary to find out the extent such undergraduates have acquired relevant skills required to make use of teleconferencing for educational purposes, have they been applying teleconferencing for teaching and learning, are they aware of benefits/gains of using teleconferencing for teaching and learning. These are the pressing issues that form the major focus of this study.

\subsection{Research Questions}

i. To what extent have undergraduates been using teleconferencing for teaching and learning?

ii. What are the most preferred or used teleconferencing components by the undergraduates?

iii. What benefits or gains are made from participating in teleconferencing?

iv. What problems are encountered by undergraduates in using teleconferencing for educational purpose?

v. What methods would undergraduates prefer to be taught with?

\section{Methodology}

The study adopted a descriptive survey design. Descriptive survey design according to Ali (2007), is a method of data collection using questionnaire or interviews to collect data from a sample that has been selected to represent a population to which the findings of the data analysis can be generalized.

The study was carried out in two federal universities namely; the University of Nigeria, Nsukka (UNN), Enugu State and Nnamdi Azikiwe University (NAU) Awka in Anambra State all in South Eastern, Nigeria. The University of Nigeria, Nsukka is categorized as First Generation University and first indigenous University that was established in 1960. The rationale for conducting this study in the two Universities (UNN and NAU) was that they have well established, structured and standard ICT facilities on the ground for teleconferencing. Also, these educational institutions have fully implemented teleconferencing as a means of teaching and learning. Secondly, these universities started computer literacy programme before other universities and the students are aware of or used to teleconferencing. That is, teleconferencing is not a new concept to the students most especially those in Faculty of Education and Vocational and Technical Education, and most of the teleconferencing competencies are taught to students during their computer literacy programme organized by Afrihub, Nigeria and the department of computer science. Thirdly, the requirements/facilities for the quality teleconferencing are made available in these universities. 
The participants for the study consisted of all the undergraduates on part $3 \& 4$ of their programmes within the Faculty of Education and Faculty of Vocational and Technical Education. The choice of chosen year III and IV students was because they have completed all the compulsory teleconferencing and computer-related courses at the Afrihub and are expected to be exploring teleconferencing for learning purposes at that stage. The data collection was preceded by visiting the two universities to find out total numbers of undergraduates that formed the population for the study. Six experts were interviewed about the effectiveness of teleconferencing in the two universities and the need for the study. The experts reported that this study was necessary.

An unstructured questionnaire titled: Effectiveness of Teleconferencing Questionnaire (ETQ) was used as an instrument for data collection and was on 4-point scale response. The questionnaire had 45 items developed for collecting data in accordance with the research questions. The questionnaire was structured in six sections. First, background information was gathered on students' age, gender, departments and faculties. Second, questions on the extent undergraduates have been using teleconferencing for teaching and learning. Third, questions on the most preferred or used teleconferencing components by the undergraduates. Fourthly, questions related to benefits or gains made from teleconferencing were addressed. Also, the problems encountered by undergraduates in using teleconferencing for educational purpose were asked and finally, questions were asked on methods undergraduates prefer to be taught with.

The ETQ was subjected to face validation by three Experts, two from Department of Industrial Technical Education, and one from Computer and Robotic Education Department, Faculty of Vocational and Technical Education, University of Nigeria, Nsukka. For experts to effectively validate the instrument, the researchers attached an introductory letter that reflects the purpose of the study, the research questions and the hypotheses formulated for the study. They were requested to use their expertise in determining the suitability of the instrument items for data collection. Their observations, corrections and suggestions were used to develop the final copy of the instrument.

The internal consistency of the questionnaire items was established using Cronbach's Alpha reliability method. A total of 20 Undergraduates of the Faculty of Education were from the University of Lagos, Lagos State in South-western Nigeria which is outside the study area were used for the pilot study. The closer the Cronbach's alpha is to 1, the higher the internal consistency (Olelewe \& Agomuo, 2016). The data collected from these students were analysed for internal consistency using Cronbach Alpha Reliability method. The reliability coefficient (Cronbach's alpha) value of 0.75 was obtained for extent of using teleconferencing for teaching and learning, 0.77 for most preferred or used teleconferencing components by the undergraduates, 0.81 for benefits or gains made from participating in teleconferencing, 0.73 for problems encountered by undergraduates in using teleconferencing for educational purpose while 0.84 was obtained as the overall reliability coefficient value for the entire questionnaire items. The statistical Packages for Social Sciences (SPSS) 22 versions (Scale) was employed to analyse the data collected from the respondents.

The survey method was chosen for real data collection in order to be able to reach a large number of subjects and obtain primary data in a cost-benefit way. Copies of unstructured questionnaire were administered on the respondents at these Universities (469), 85.07\% (399) of whom responded. This is an acceptable response rate according to a study by Baruch (1999) who recommended a standard of $60+/-20 \%$ for surveys in managerial and behavioural sciences.

The subjects responded to the items which responses were analysed in SPSS, using descriptive statistics (quantitative methods) of percentage to deal with the research questions. 


\section{Results}

\section{Sample Characteristics}

The empirical data covered undergraduates on 300 and 400 levels in the two universities chosen for the study. The respondents' profile is presented in Table 1.

Table 1. Profile of Responding Experts

\begin{tabular}{|c|c|}
\hline Respondent profile & $\begin{array}{l}\text { \% of valid responses } \\
\text { (number in bracket) }\end{array}$ \\
\hline \multicolumn{2}{|l|}{ University affiliation $(n=399)$} \\
\hline UNN & $\begin{array}{l}56.14 \% \\
(224)\end{array}$ \\
\hline NAU & $\begin{array}{c}43.86 \% \\
(175) \\
\end{array}$ \\
\hline \multicolumn{2}{|l|}{ Faculty affiliation $(n=399)$} \\
\hline Education & $\begin{array}{l}80 \% \\
(319)\end{array}$ \\
\hline Vocational and Technical Education & $\begin{array}{l}20 \% \\
(80) \\
\end{array}$ \\
\hline \multicolumn{2}{|l|}{ Median Age (n=399) } \\
\hline All valid responses & 18years \\
\hline \multicolumn{2}{|l|}{ Gender $(n=399)$} \\
\hline Male & $\begin{array}{l}44 \% \\
(176)\end{array}$ \\
\hline Female & $\begin{array}{l}56 \% \\
(223)\end{array}$ \\
\hline
\end{tabular}

Results of data analysis Table 1 shows that the demographic characteristics of respondents in the sampled universities were as follows: $56.14 \%$ (224) from the UNN, and $43.86 \%$ (175) from NAU. The median age of respondents was 18. Of the respondents $223(56 \%)$ were female, whilst $176(44 \%)$ were male. Most of the respondents $(319 ; 80 \%)$ were undergraduates in the faculty of education while the remaining respondents (80; $20 \%$ ) were students of Vocational and Technical Education faculty. Few students in the faculty of VTE could be associated with fact that VTE is a new faculty at UNN. This, therefore, guarantees the validity of the responses.

Results of data analysis in Table 2 answered research question one and two. The data reveal that the following teleconferencing components are rated high extent by most of the undergraduates of the UNN and NAU: audio conferencing $(399 ; 100 \%)$, computer conferencing $(384 ; 96.24 \%)$, e-mail $(378 ; 94.74 \%)$, Facebook $(377 ; 94.49 \%)$, WhatsApp $(380 ; 95.24 \%)$, video phone (IMO) $(236 ; 59.15 \%)$. This indicated that undergraduates frequently make use of aforemention0ed teleconferencing components/tools. It also means that students mostly preferred to use teleconferencing components. 
Table 2. Respondents' Answer on Extent of Using Teleconferencing for Teaching and Learning Purposes

\begin{tabular}{|c|c|c|c|}
\hline \multirow[b]{2}{*}{ S/No } & \multirow[b]{2}{*}{ Items } & \multicolumn{2}{|c|}{ Responses } \\
\hline & & High extent & Low extent \\
\hline 1 & Audio conferencing & $\begin{array}{c}399 \\
(100 \%)\end{array}$ & 0 \\
\hline 2 & Video conferencing & $\begin{array}{c}123 \\
(30.83 \%)\end{array}$ & $\begin{array}{c}276 \\
(69.17 \%)\end{array}$ \\
\hline 3 & Multimedia conferencing & $\begin{array}{c}110 \\
(27.56 \%)\end{array}$ & $\begin{array}{c}289 \\
(72.43 \%)\end{array}$ \\
\hline 4 & Computer conferencing & $\begin{array}{c}384 \\
(96.24 \%)\end{array}$ & $\begin{array}{c}15 \\
(3.76 \%)\end{array}$ \\
\hline 5 & Graphic communication & $\begin{array}{c}101 \\
(25.31 \%)\end{array}$ & $\begin{array}{c}298 \\
(74.68 \%)\end{array}$ \\
\hline 6 & Video-graphic conferencing & $\begin{array}{c}98 \\
(24.56 \%)\end{array}$ & $\begin{array}{c}301 \\
(75.43 \%)\end{array}$ \\
\hline 7 & Audiographic conferencing & $\begin{array}{c}121 \\
(30.33 \%)\end{array}$ & $\begin{array}{c}278 \\
(69.67 \%)\end{array}$ \\
\hline 8 & Business television & $\begin{array}{c}43 \\
(10.78 \%)\end{array}$ & $\begin{array}{c}356 \\
(89.22 \%)\end{array}$ \\
\hline 9 & Distance education & $\begin{array}{c}134 \\
(33.58 \%)\end{array}$ & $\begin{array}{c}265 \\
(66.41 \%)\end{array}$ \\
\hline 10 & Facsimicle & $\begin{array}{c}69 \\
(17.29 \%)\end{array}$ & $\begin{array}{c}330 \\
(82.71 \%)\end{array}$ \\
\hline 11 & e-mail & $\begin{array}{c}378 \\
(94.74 \%)\end{array}$ & $\begin{array}{c}21 \\
(5.26 \%)\end{array}$ \\
\hline 12 & Facebook & $\begin{array}{c}377 \\
(94.49 \%)\end{array}$ & $\begin{array}{c}22 \\
(5.51 \%)\end{array}$ \\
\hline 13 & Whatsapp & $\begin{array}{c}380 \\
(95.24 \%)\end{array}$ & $\begin{array}{c}19 \\
(4.76 \%)\end{array}$ \\
\hline 14 & Video phone & $\begin{array}{c}236 \\
(59.15 \%)\end{array}$ & $\begin{array}{c}163 \\
(40.85 \%)\end{array}$ \\
\hline 15 & Telepresentation & $\begin{array}{c}78 \\
(19.55 \%)\end{array}$ & $\begin{array}{c}321 \\
(80.45 \%)\end{array}$ \\
\hline 16 & Tele teaching & $\begin{array}{c}76 \\
(19.08 \%)\end{array}$ & $\begin{array}{c}323 \\
(80.95 \%)\end{array}$ \\
\hline
\end{tabular}




\section{Table 3. Students' Responses on Benefits in Participating in} Teleconferencing

\begin{tabular}{|c|c|c|c|c|c|}
\hline \multirow[b]{2}{*}{ S/No } & \multirow[b]{2}{*}{ Items } & \multicolumn{4}{|c|}{ Responses } \\
\hline & & $\begin{array}{l}\text { In all } \\
\text { cases }\end{array}$ & $\begin{array}{l}\text { In some } \\
\text { cases }\end{array}$ & $\begin{array}{c}\text { In few } \\
\text { cases }\end{array}$ & $\begin{array}{l}\text { In no } \\
\text { case }\end{array}$ \\
\hline 1 & Boost morale for learning & $\begin{array}{c}300 \\
(75.19 \%)\end{array}$ & $\begin{array}{c}99 \\
(24.81 \%)\end{array}$ & 0 & 0 \\
\hline 2 & $\begin{array}{l}\text { Help in sharing experiences } \\
\text { with other colleagues }\end{array}$ & $\begin{array}{c}299 \\
(74.93 \%)\end{array}$ & $\begin{array}{c}100 \\
(25.06 \%)\end{array}$ & 0 & 0 \\
\hline 3 & Raise unexpected issues & $\begin{array}{c}278 \\
(69.67 \%)\end{array}$ & $\begin{array}{c}109 \\
(27.32 \%)\end{array}$ & $\begin{array}{c}12 \\
(3.01 \%)\end{array}$ & 0 \\
\hline 4 & $\begin{array}{l}\text { Build students retention of } \\
\text { learning }\end{array}$ & $\begin{array}{c}389 \\
(97.49 \%)\end{array}$ & $\begin{array}{c}10 \\
(2.51 \%)\end{array}$ & 0 & 0 \\
\hline 5 & $\begin{array}{l}\text { Improve students' explanatory } \\
\text { capacity }\end{array}$ & $\begin{array}{c}311 \\
(77.94 \%)\end{array}$ & $\begin{array}{c}88 \\
(22.06 \%)\end{array}$ & 0 & 0 \\
\hline 6 & Provide different perspectives & $\begin{array}{c}300 \\
(75.19 \%)\end{array}$ & $\begin{array}{c}99 \\
(24.81 \%)\end{array}$ & 0 & 0 \\
\hline 7 & Making ideas more clearer & $\begin{array}{c}376 \\
(94.24 \%)\end{array}$ & $\begin{array}{c}23 \\
(5.76 \%)\end{array}$ & 0 & 0 \\
\hline 8 & Simplify difficult concepts & $\begin{array}{c}378 \\
(94.74 \%)\end{array}$ & $\begin{array}{c}21 \\
(5.26 \%)\end{array}$ & 0 & 0 \\
\hline 9 & $\begin{array}{l}\text { Providing wide scope of } \\
\text { discussion }\end{array}$ & $\begin{array}{c}399 \\
(100 \%)\end{array}$ & 0 & 0 & 0 \\
\hline 10 & $\begin{array}{l}\text { Presentation of ideas becomes } \\
\text { easier for students }\end{array}$ & $\begin{array}{c}389 \\
(97.49 \%)\end{array}$ & $\begin{array}{c}10 \\
(2.51 \%)\end{array}$ & 0 & 0 \\
\hline 11 & $\begin{array}{l}\text { Reinforce positive self } \\
\text { concept }\end{array}$ & $\begin{array}{c}299 \\
(74.94 \%)\end{array}$ & $\begin{array}{c}88 \\
(22.06 \%)\end{array}$ & $\begin{array}{c}12 \\
(3.01 \%)\end{array}$ & 0 \\
\hline 12 & $\begin{array}{l}\text { Encouraging students to } \\
\text { repeat concepts for mastery }\end{array}$ & $\begin{array}{c}369 \\
(92.48 \%)\end{array}$ & $\begin{array}{c}30 \\
(7.52 \%)\end{array}$ & 0 & 0 \\
\hline 13 & $\begin{array}{l}\text { Eliminating isolation of } \\
\text { participants }\end{array}$ & $\begin{array}{c}391 \\
(97.99 \%)\end{array}$ & $\begin{array}{c}8 \\
(2.01 \%)\end{array}$ & 0 & 0 \\
\hline 14 & Showing what is important & $\begin{array}{c}312 \\
(78.19 \%)\end{array}$ & $\begin{array}{c}76 \\
(19.05 \%)\end{array}$ & $\begin{array}{c}11 \\
(2.76 \%)\end{array}$ & 0 \\
\hline 15 & $\begin{array}{l}\text { Enable participants sharing } \\
\text { series of pressing issues or } \\
\text { problems }\end{array}$ & $\begin{array}{c}391 \\
(97.99 \%)\end{array}$ & $\begin{array}{c}8 \\
(2.01 \%)\end{array}$ & 0 & 0 \\
\hline 16 & $\begin{array}{l}\text { Provide good communal } \\
\text { atmosphere for every } \\
\text { beginners }\end{array}$ & $\begin{array}{c}322 \\
(80.70 \%)\end{array}$ & $\begin{array}{c}77 \\
(19.30 \%)\end{array}$ & 0 & 0 \\
\hline
\end{tabular}

All the students concurred that teleconferencing cannot be said to be of any value in any case, rather all the students are of the opinion that teleconferencing provides a wide range of benefits. Data in Table 3 on research question 2 therefore show that, majority of students agreed that teleconferencing boost morale for learning, help in sharing experiences with other colleagues, build ones' retention of learning, improve students' explanatory capacity, provide different perspectives, make ideas clearer, simplify difficult concepts, providing wide scope of discussion, and make presentation of ideas easier. Majority of students also believe that teleconferencing encourages students to repeat concepts for mastery, eliminate isolation of participants, enables participants sharing series of pressing issues or problems, provides a good communal atmosphere for every beginner, shows what is important, reinforces positive self-concept and help in raising unexpected issues in some cases. 
Table 4. Respondents View of the Problems encountered in Using Teleconferencing for Educational Purpose

\begin{tabular}{|c|c|c|c|c|c|}
\hline \multirow[b]{2}{*}{ S/No } & \multirow[b]{2}{*}{ Items } & \multicolumn{4}{|c|}{ Responses } \\
\hline & & $\begin{array}{l}\text { Very } \\
\text { serious }\end{array}$ & Serious & $\begin{array}{l}\text { Not so } \\
\text { serious }\end{array}$ & $\begin{array}{l}\text { Not } \\
\text { serious at } \\
\quad \text { all }\end{array}$ \\
\hline 1 & $\begin{array}{l}\text { Lack of crop of technicians to } \\
\text { maintain } \\
\text { gadgets }\end{array}$ & $\begin{array}{c}388 \\
(97.24 \%)\end{array}$ & $\begin{array}{c}11 \\
(2.76 \%)\end{array}$ & 0 & 0 \\
\hline & $\begin{array}{l}\text { High cost of teleconference } \\
\text { equipment }\end{array}$ & $\begin{array}{c}399 \\
(100 \%)\end{array}$ & 0 & 0 & 0 \\
\hline 2 & $\begin{array}{l}\text { High cost of maintenance of } \\
\text { teleconference equipment }\end{array}$ & $\begin{array}{c}399 \\
(100 \%)\end{array}$ & 0 & 0 & 0 \\
\hline 3 & Consistent power failure & $\begin{array}{c}399 \\
(100 \%)\end{array}$ & 0 & 0 & 0 \\
\hline 4 & $\begin{array}{l}\text { Inadequacy of teleconferencing } \\
\text { equipment }\end{array}$ & $\begin{array}{c}389 \\
(97.49 \%)\end{array}$ & $\begin{array}{c}9 \\
(2.26 \%)\end{array}$ & $\begin{array}{c}1 \\
(0.25 \%)\end{array}$ & 0 \\
\hline 5 & $\begin{array}{l}\text { Lack of genuine teleconference } \\
\text { equipment }\end{array}$ & $\begin{array}{c}300 \\
(75.19 \%)\end{array}$ & $\begin{array}{c}99 \\
(24.81 \%)\end{array}$ & 0 & 0 \\
\hline 6 & $\begin{array}{l}\text { Non availability of computer in } \\
\text { most Nigerian homes }\end{array}$ & $\begin{array}{c}399 \\
(100 \%)\end{array}$ & 0 & 0 & 0 \\
\hline 7 & $\mathrm{C}$ & $\begin{array}{c}387 \\
(96.99 \%)\end{array}$ & $\begin{array}{c}12 \\
(3.01 \%)\end{array}$ & 0 & 0 \\
\hline 8 & $\begin{array}{ll}\text { Non availability } & \text { of } \\
\text { teleconference equipment } & \text { in } \\
\text { the universities } & \end{array}$ & $\begin{array}{c}179 \\
(44.86 \%)\end{array}$ & $\begin{array}{c}78 \\
(19.55 \%)\end{array}$ & $\begin{array}{c}142 \\
(35.59 \%)\end{array}$ & 0 \\
\hline 9 & $\begin{array}{l}\text { Low level of students } \\
\text { competencies in using } \\
\text { teleconference equipment }\end{array}$ & $\begin{array}{c}320 \\
(80.20 \%)\end{array}$ & $\begin{array}{c}79 \\
(19.80 \%)\end{array}$ & 0 & 0 \\
\hline 10 & $\begin{array}{l}\text { Acute shortage of } \\
\text { specialists }\end{array}$ & $\begin{array}{c}399 \\
(100 \%)\end{array}$ & 0 & 0 & 0 \\
\hline 11 & Frequent network failure & $\begin{array}{c}300 \\
(75.18)\end{array}$ & $\begin{array}{c}99 \\
(24.81)\end{array}$ & & \\
\hline
\end{tabular}

Results of data analysis in Table 4 for research question three show that every problem which the undergraduates encounter in teleconferencing are considered as very serious ones. The worst and the most serious cases are: the high cost of teleconference equipment, the high cost of maintenance of teleconference equipment, consistent power failure, unavailability of a computer in most Nigerian homes, frequent network failure and acute shortage of ICT specialists

Table 5. Respondents' views on the Method of Teaching they prefer to be taught With

\begin{tabular}{cccccc}
\hline \multirow{2}{*}{ S/No } & \multirow{2}{*}{ Items } & In all & Responses & \\
& & cases & cases & In few & In no \\
cases & case \\
\hline 1 & Teleconferencing components & 101 & 298 & 0 & 0 \\
\multirow{2}{*}{2} & \multirow{2}{*}{ Teaching methods } & $(25.31 \%)$ & $(74.69 \%)$ & & \\
& & 29 & 92 & 278 & 0 \\
& & $(7.27 \%)$ & $(23.06 \%)$ & $(69.67 \%)$ & \\
\hline
\end{tabular}


Results of data analysis in Table 5 show that $101(25.31 \%)$ want to be taught by using teleconferencing components all the time, while 298 (74.69\%) of the undergraduates involved in the study prefer to be taught in some of the times using teleconferencing, $29(7.27 \%)$ still accept teaching methods while $92(23.06 \%)$ prefer to be taught with teaching methods in sometimes, while $278(69.67 \%$ ) of the students still prefer to be taught in few cases. This is an indication that students are really yearning for innovation.

\section{Discussion of Findings}

Teaching with modern technologies in Nigerian universities is one of the major challenges we are facing. We set up this study to investigate the utilization of teleconferencing for educational purposes and the following findings emerged. Audio conferencing, video, conferencing, WhatsApp, facebook, email, computer conferencing are mostly used by undergraduates in Faculty of Education and Faculty of Vocational and Technical Education, University of Nigeria, Nsukka and Nnamdi Azikiwe University, Awka, while others teleconferencing such as multimedia conferencing, graphic communication, video-graphic conferencing, audiographic conferencing, business television, distance education, facsimile, teleteaching, and telepresentation are hardly utilized for teaching and learning and this could be as a result of technical skills required for using them and cost of purchasing them. The results have therefore shown that students of UNN and NAU have benefited greatly from the compulsory computer courses mounted for them hence a good number of them use teleconferencing tools/components to further their learning as well as teach their fellow students to an appreciable extent. The undergraduates of these institutions also prefer to be taught or use the mentioned components of teleconferencing. This finding is in agreement with the opinion of Akudolu (2004) that students who are computer literate have advantages over others naturally in their application of computer for educational purposes. The provision made by universities to ensure that every student is computer literate is therefore not in vain.

The undergraduates of these institutions also ascertained that using teleconferencing for teaching and learning results in boosting their morale for learning, help in sharing experiences with other colleagues, build their retention of learning, improve students' explanatory capacity, provide them different perspectives, make ideas more clearer to them, simplify difficult concepts, provide them wide scope of discussion, eliminate isolation of participants, encourage them to repeat concepts for mastery, and enable participants to share series of pressing issues or problems. This finding is in consonance with the finding of Adirika and Alike (2008) who conducted a study on utilization of ICT for teaching and learning in schools and colleges, discovered that some technologies such as a computer, email, cell phones, Ipads among others are found beneficial in teaching and learning of school subjects. Information and telecommunication technologies are found useful when there is a need for acquiring lifelong and modern workplace skills. According to Ekoja (2007), information and communication technology is the equipment used for capturing, processing, storing, transmitting and accessing information, which has offered librarians and other information professionals' tremendous opportunities in information handling. Utilization of ICTs such as computers, internet, database, hard disks, projectors, public address systems, and using of interactive television is necessary for achieving quality teaching of courses in schools and colleges (Gambari \& ChikeOkoli, 2007).

The study also considered lack of crop of technicians to maintain teleconference gadgets, high cost of teleconference equipment, high cost of maintenance of teleconferencing equipment, consistent power failure, inadequate teleconferencing equipment, unavailability of computer in most Nigerian homes, unavailability of teleconference equipment in the universities, acute shortage of ICT specialists, low level of students competencies in using teleconferencing equipment as very serious problems in 
utilizing teleconferencing for teaching and learning. This finding agreed with the opinion of Igbokwe \& Eze (2008) that instability of power supply is one of the major problems facing the users of various information and communication technologies in Nigeria. The issue of the instability of power supply is a major problem because every teleconferencing tool needs a power supply for their operation and when there is power outbreak, the tools or other electronic related gadgets become useless. Also, the finding agreed with the results of Issa, Ayodele, Abubakar, \& Aliyu (2011) who conducted a study and found that frequent power failure is a major constraint to the application of information technology to library services at the federal university of technology, Akure library, Ondo State, Nigeria. Acute shortage of ICT specialists also considered as one of the major problems in the utilization of teleconferencing for educational purposes. This finding agreed with the finding of Aramide and Bolarinwa (2010) who conducted a study at the National Open University of Nigeria (NOUN), Ibadan Study Centre where they found that "the major constraints hindering the use of audiovisual and electronic resources include poor power supply, poor infrastructure, lack of adequate skill, high cost, and unavailability. There are few ICT specialists in schools and out of these few majorities of them are skilled in rectifying all kinds of faults occur to teleconferencing tools or components and this, therefore, makes it so difficult for individuals to use. That is why some of the lecturers in tertiary institutions prefer to make use of traditional methods of teaching for implementing almost every school subjects without considering modern strategies that could equip students with lifelong and workplace skills.

The study also revealed that students prefer to be taught using teleconferencing in some cases and most of them also prefer to be taught in few cases. That is, students, wish to learn new things through technology. This finding agreeing with the submission of Alegbemi (2016) that the computer has various advantages over the traditional classroom culture. This finding was also supported by Schnotz and Bannert, (2003), who stated that teaching students with computer-related strategies, improve their understanding and gives them a retentive memory.

\section{Conclusion}

We set up this study to investigate the extent of utilizing teleconferencing for teaching and learning in Nigerian universities. It is not proper to start discussing emerging reforms in Nigerian universities without investigating the extent of utilizing some of these educational innovations. The finding of the study shows that teleconferencing is very welcome and accepted by university students as strategies for acquiring new knowledge, skills and attitudes.

\section{Recommendations}

Based on the finding of the study, we, therefore, recommend that:

i. University lecturers and students should be retrained on how to make use of more teleconferencing tools for teaching and learning

ii. Other tertiary institutions should start exposing their students and teachers to training in teleconferencing

iii. Teleconferencing enhancement facilities should be supplied to schools and colleges for the purpose of teaching and learning

\section{References}

[1] D. R. Carl, "Creating a Duet: Using Video and Video Teleconferencing to Meet the Needs of the Community", Programmed Learning and Educational Technology, (1983), pp. 187-189.

[2] D. J. Gemmell and C. G. Bell, "Noncollaborative Telepresentations Come of Age", Communications of the ACM, vol. 40, no. 4, (1997), pp. 79-89. 
[3] C.J. Olelewe, and E.E. Agomuo, "Effects of b-learning and f2f learning environments on students' achievement in QBASIC programming. Computer \& Education, vol. 103 (2016), pp. 76-86.

[4] Y. Sung, K. Chang and T. Liu, "The effects of integrating mobile devices with teaching and learning on students' learning performance: A meta-analysis and research synthesis", Computers and Education, vol. 94(2016), pp. 252-275

[5] H.I. Schnotz and S.M. Bennert, "Information and Communication Technology in Schools", Journal of Information Technology for Teacher Education, vol. 5, no. 3 (2003), pp. 217 - 218.

[6] M. Drent and M. Meelissen, Which Factors Obstruct or Stimulate Teacher Educators to Use ICT Innovatively? Journal of Computers \& Education, (2007).

[7] L.M. Ekoja, L. M. Technology for Leadership in the Twenty-first Century. Journal of Educational Administration, vol. 41, no. 2(2007), pp. 124-142

[8] K. Gambari and N. Chike-Okoli, "Application and uses of information and communication technology in schools and colleges", Journal of Teacher Education, vol. 6, no. 4(2007), pp. 27 - 37

[9] F.C. Nwosu and A.L. Chijioke, "Computer education in the 21 st century: A vital resources for selfactualization and sustainability. A Multidisciplinary Journal, vol.11, no. 8(2005), pp. 21-24

[10] L.R. Akudolu, "Computer-assisted teaching and learning", John Jacobs Classic Publishers Limited, Enugu (2004).

[11] Commonwealth Educational Media Centre for Asia "Teleconferencing, a training Kit", Commonwealth Educational Media Centre for Asia, India (2004).

[12] Federal Government of Nigeria, "National Policy on Education", NERDC, Abuja (2008).

[13] A. Inglis, P. Ling and V. Joosten, "Delivering Digitally: Managing the Transition to the Knowledge Media", Kogan Page, London(2002).

[14] H. P. Lorne, "Teleconferencing in Education", Clearinghouse, New York(1983).

[15] H.R. McCarty, "Teleconferencing-A Cost Effective Communications Service", County Department of Education, San Diego, CA San Diego (1981).

[16] E.O. Oguguo, "Basic of information technology" Rhyce Kerex Publishers, Enugu, (2005).

[17] C.H. Olgren and H. P.Lorne, "Teleconferencing status and trends for electronic communication", Center for Interactive Programs, University of Wisconsin Extension, Madison, WI, (1982).

[18] B.N. Adirika and G.U. Alike, "Utilization of ICT for teaching and learning in tertiary institution: A case study of Nnamdi Azikiwe University, Awka", Edited B.G. Nworgu, University Trust Publishers, Nsukka, (2008), pp. 172-177.

[19] U.L. Igbokwe and U.N. Eze, "Innovative practices for effective teaching of English language for quality assurance in secondary schools. Edited B.G. Nworgu, University Trust Publishers, Nsukka, (2008).

[20] S.O. Olaitan, E.C. Osinem, A.B. Hontonyon, and M.A. Akeju, "Performance competencies required by lecturers for application of micro-computers for the teaching of agriculture in colleges of education in the south-west, Nigeria. Edited B.G. Nworgu, University Trust Publishers, Nsukka (2008), pp. 172-177

[21] F. Alegbemi, "The extent of utilization of information and communication technology for teaching of electronic technology in colleges of education in northwestern zone of Nigeria.M.Ed Thesis, University of Nigeria, Nsukka, (2016).

[22] J. Bakare, "Development and validation of cell phone maintenance training modules for national diploma students", Ph.D Thesis, University of Nigeria, Nsukka (2014).

[23] C. Arapis, D. Konstantas, T. Pilioura, "Design Issues and Alternatives for Setting up Real-time Interactive Telelectures", Proceedings of the 1998 ACM Symposium on Applied Computing (SAC 98), (1998), pp. 104-111.

[24] C. Breiteneder, S. Gibbs, C. Arapis, "Teleport-An Augmented Reality Teleconferencing Environment",3rd Eurographics Workshop on Virtual Environments, Monte Carlo, Monaco, (1996).

[25] K. A. Aramide and O. M. Bolarin, "Availability and Use of Audiovisual and Electronic Resources by Distance Learning Students in Nigerian Universities: a Case Study of National Open University of Nigeria (NOUN), Ibadan Study Centre", Library Philosophy and Practice. Available at: http://unllib.unl.edu/LPP/aramide.htm, (2010).

[26] A. O. Issa, A. E. Ayodele, U. Abubakar and M. B. Aliyu, "Application of Information Technology to Library Services at the Federal University of Technology, Akure Library, Ondo State, Nigeria”, Library Philosophy and Practice. http://unllib.unl.edu/LPP/, (2011).

[27] S. Shervin and C. Jauvane, "Teleconferencing - Introduction, Services and Requirement Standards", http://encyclopedia.jrank.org/articles/pages/6908/Teleconferencing.html, (2017). 